Jurnal Info Kesehatan

Vol.18, No.1, June 2020, pp. 50-58

P-ISSN 0216-504X, E-ISSN 2620-536X

DOI: 10.31965/infokes.Vol18.Iss1.311

Journal homepage: http://jurnal.poltekeskupang.ac.id/index.php/infokes

R E S E A R C H

\title{
Antenatal Education with Booklet Media on Knowledge and Readiness of Pregnant Women under the Age of 20 Years
}

\author{
Ni Putu Karunia Ekayani ${ }^{1 a^{*}}$, Nurmayasari ${ }^{1 \mathrm{~b}}$, Intan Gumilang ${ }^{\text {1c }}$ \\ ${ }^{1}$ Department of Midwifery, Poltekkes Kemenkes Mataram, Indonesia \\ ${ }^{a}$ Email address: karuniaekayani80@gmail.com \\ ${ }^{\mathrm{b}}$ Email address: nurmayasarimaya97@gmail.com \\ c Email address: intangumil@gmail.com
}

Received: 12 November 2019

Revised: 15 June 2020

Accepted: 26 June 2020

\begin{abstract}
West Nusa Tenggara Province is one of the areas with high early marriage cases in Indonesia. Pregnancy of women aged 10-19 years who had been pregnant reached 58.8\% and currently pregnant $25.2 \%$. The objective of this study is to determine the effect of antenatal education with the booklet media on the knowledge and readiness of pregnant women under the age of 20 in dealing with pregnancy. This research is a quasi- experiment with one group pretest-posttest. This research was conducted in May-June 2019. The population in this study was pregnant women under the age of 20 years. The sampling technique in this study was total sampling with a sample of 30 pregnant women. The analysis used Wilcoxon Sign Rank Test and Paired Sample T Test. The results showed that respondents in this study were 16-19 years old with the majority of secondary education and all working as housewives. There was an increase in the value of the level of knowledge and readiness from before and after the intervention was given. Statistical test results on the level of knowledge and readiness obtained $p$ value $=0.000$ before and after given the intervention, showing the influence of antenatal education on the knowledge and readiness of pregnant women under 20 years of age in dealing with pregnancy. Future studies are expected to add to a larger sample size and add other relevant variables related to pregnancies under the age of 20 years.
\end{abstract}

Keywords: Antenatal Education, Booklet Media, Knowledge, Readiness, Pregnant Women

\footnotetext{
*Corresponding Author:

Ni Putu Karunia Ekayani

Department of Midwifery, Poltekkes Kemenkes Mataram

Gora Street, Gang Sirsak, No.14 Sindu Cakranegara, Mataram, West Nusa Tenggara, Indonesia

Email: karuniaekayani80@gmail.com

(C) The Author(s) 2020. This article is distributed under the terms of the Creative Commons Attribution 4.0 International License (http://creativecommons.org/licenses/by/4.0/), which permits unrestricted use, distribution, and reproduction in any medium, provided you give appropriate credit to the original author(s) and the source, provide a link to the Creative Commons license, and indicate if changes were made. The Creative Commons Public Domain Dedication waiver (http://creativecommons.org/publicdomain/zero/1.0/) applies to the data made available in this article, unless otherwise stated.
} 


\section{INTRODUCTION}

Data from the Demographic and Health Survey of Indonesia (DHSI) 2017 found that the median age at first marriage for all women aged 25-49 years was 20.8 years. In married women aged 25-49 years was 21.8 years and married men aged 25-49 years were 24.6 years (Badan Pusat Statistik, 2017). The median age at first marriage for women ever married 25-49 years continued increasing from 17.1 years in 1991 to 21.8 years in the 2017 Demographic and Health Survey. The median age at first marriage for married women aged 25-49 years living in urban areas is higher (22.9 years) compared to those living in rural areas (20.9 years) (Badan Pusat Statistik, 2017). Based on data from the Central Statistics Agency in 2017, the distribution of child marriages above $10 \%$ is evenly distributed in all provinces in Indonesia while for the distribution of early marriage rates above $25 \%$ are in 23 provinces out of 34 provinces in Indonesia, so based on these data, it can be concluded that $67 \%$ of the region in Indonesia is an emergency area for child marriages. (Badan Pusat Statistik, 2017).

From the 2018 Basic Health Research data, it was found that pregnancy women aged 10-54 years who had married in the province of West Nusa Tenggara reached $94.1 \%$ and those who were 5.6\% pregnant. For pregnancy among women aged 10-19 years (adolescents) who have been pregnant as much as $58.8 \%$, and those who are pregnant $25.2 \%$ (Kementerian Kesehatan, R.I., 2018). It shows that child marriage and pregnancy that occurs under the age of 20 years in West Nusa Tenggara are still high. Marriage to young women invites risks, especially in infants to be born, including the risk of complications, which are low birth weight babies, prematurity, asphyxia, fetal growth stunted, motor and cognitive development delays. Therefore, adolescent girls should be prepared physically including adequate nutrition and prevention of anemia. Furthermore, the most important thing is increasing knowledge about pregnancy care and delivery readiness (Nendra et al., 2006). In addition to the impact on the baby being conceived, pregnancy at a young age can also have an impact on the mother herself. Young pregnant women are one of the risk factors during pregnancy that can result in death for the pregnant women. Most of the complications that occur during pregnancy can actually be prevented by making pre-conception. Increasing the knowledge and readiness of pregnant women in dealing with pregnancy is very essential, especially pregnant women who have no prior experience of dealing with pregnancy, especially mothers at a young age. Health education is very useful in preventing risk factors that can affect pregnancy among other malnutrition, complaints and effects of changes during pregnancy, stress or psychological factors of pregnancy, risk of miscarriage, premature labor, low birth weight and sudden fetal death, and also the effects of problematic health conditions during pregnancy (Oktalia, J \& Herizasyam, 2016). Efforts in increasing the knowledge and readiness of mothers in encountering their pregnancy can be done through the provision of effective and optimal health education. Health education can be provided through the media, one of which is the booklet media. Booklets are pictorial and written media that convey messages to facilitate understanding of the material presented because they are packaged as attractive as possible (Zulaikah, S., 2012). From the data of the Central Statistics Agency of West Nusa Tenggara 2018, the number of incouples of childbearing age under the age of 20 years in each regency/city is in the city of Mataram, the number of incouples of childbearing age under 20 years is 1,010 people, West Lombok Regency 6,067 people, and North Lombok Regency 1,594 people (Badan Pusat Statistik Kota Mataram, 2017) . Of the three districts, the highest number of Childbearing Age Pairs under the age of 20 
years is in West Lombok Regency (Badan Pusat Statistik Lombok Barat, 2018). The number of couples of childbearing age under 20 years old in West Lombok Regency in 2018 is highest in Lembar and Gerung districts with a total of 1,074 people. The results of a preliminary study conducted at the UPT BLUD Primary Health Center, Gerung from May-June 2019 showed results of pregnant women under the age of 20 years totaling 30 pregnant women. Based on Basic Health Research Results, 2018 as many as $27.8 \%$ of adolescents experienced problems or disorders/complications of pregnancy in childbirth. Hence, pregnant adolescents need to get more effective and efficient attention and intervention regarding pregnancy and childbirth preparation so that in this study it can be identified the effect of antenatal education with booklet medias on the knowledge and readiness of pregnant women under the age of 20 in dealing with pregnancy and childbirth. This research used booklet media in its intervention to pregnant women under 20 years which is explained through health education methods with emphasis on material on booklets about the risk of pregnancy under 20 years, pregnancy care until pregnancy adolescent readiness to face childbirth that is easily understood by pregnant teenagers.

\section{RESEARCH METHOD}

This study used a type of pre-experimental research using one group pretestposttest without control group design. This study intervened in one group without comparison. The sampling technique in this study was that 30 pregnant women under the age of 20 who met the inclusion criteria were pregnant women under the age of 20 who were willing to take part in the research and were able to read and write while the exclusion criteria for this study were pregnant women who experienced maternal and neonatal emergencies. The research instrument used booklet media. This research began with obtaining approval of ethical studies and in conducting research, the data is obtained by giving questionnaires to respondents then providing health education about pregnancy, risk of pregnancy under the age of 20 years, signs of pregnancy, danger signs of pregnancy, pregnancy discomfort, antenatal care, benefits of ultrasound, the importance of blood-added tablets, pregnancy care, baby care, and delivery preparation using the booklet media. Then, post-test was performed. For scoring on the knowledge of pregnant women under the age of 20 years, it used a questionnaire given a score: Value 1, if the answer is correct. Value of 0 is for the wrong answer. Readiness of pregnant women under the age of 20 used a questionnaire that was given a score. The statistical test used for knowledge was the Wilcoxon Sign Rank Test while the statistical test used for readiness is the Paired Sample T Test. This study has received ethical approval from the Ethics Commission of the Health Polytechnic of the Ministry of Health, Mataram Number: LB.01.03/1.1/3353/2019.

\section{RESULTS AND DISCUSSION}

Table 1. Distribution of Characteristics of Antenatal Education Respondents with Booklet Medias on Knowledge and Readiness of Pregnant Women Under 20 Years Old.

\begin{tabular}{lcc}
\hline Characteristic & n & \% \\
\hline Age & & \\
\hline$<15-17$ years & 5 & 16,7 \\
\hline $18-20$ years & 20 & 66,6 \\
\hline Education & & \\
\hline Primary School & 1 & 3,3 \\
\hline
\end{tabular}


Ekayani, N. P. K., Nurmayasari \& Gumilang, I. (2020). Antenatal Education with Booklet Media on Knowledge and Readiness of Pregnant Women under the Age of 20 Years. JURNAL INFO KESEHATAN, 18(1), 50-58. https://doi.org/10.31965/infokes.Vol18.Iss1.311

\begin{tabular}{lcc}
\hline Junior High School & \multicolumn{5}{|c}{} & 63.4 \\
\hline Senior High School & 10 & 33,3 \\
\hline Occupation & & \\
\hline Housewife & 30 & 100
\end{tabular}

Table 1 shows that most pregnant women aged 18-20 years as many as 20 people (66.6\%) had 19 junior high school education (63.4\%), and 30 housewives (100\%).

Table 2. Characteristics of Knowledge and Readiness of Pregnant Women about Pregnancy Care

\begin{tabular}{lcccc} 
Frequency Distribution & n & Minimum & Maximum & Mean \\
\hline Before intervention & & & & \\
\hline Knowledge & 30 & 3 & 7 & 4,73 \\
\hline Readiness & 30 & 24 & 32 & 27,63 \\
\hline After intervention & & & & \\
\hline Knowledge & 30 & 8 & 10 & 9,23 \\
\hline Readiness & 30 & 28 & 36 & 31,93 \\
\hline
\end{tabular}

Table 2 shows that the level of knowledge and readiness of the mother before being given antenatal education with the booklet media, the average score of knowledge is 4.73 while for the preparedness, the average score is 27.63 and there is an increase in the knowledge and readiness of the mother after being given antenatal education with the booklet media, the average score of knowledge is 9.23.

Table 3. Results of Antenatal Education with Booklet Medias Effects Analysis on Knowledge Levels of Pregnant Women Under the Age of 20 Years in Dealing with pregnancy.

\begin{tabular}{lccc}
\hline \multicolumn{1}{c}{ Pengetahuan } & n & Mean Rank & p-value \\
\hline Before & 30 & 0,00 & 0.000
\end{tabular}

Table 4 shows that the mean rank of knowledge of pregnant women under 20 years of age before being given antenatal education with the booklet media was 0.00 , whereas after being given antenatal education with the booklet media, the mean rank was 15.50. Based on statistical tests, it obtained $p$ value $=0,000$, so it can be concluded that there is a significant influence on the level of knowledge of pregnant women under the age of 20 in dealing with pregnancy.

Table 4. Results of Antenatal Education with Booklet Medias Effects Analysis on the Readiness Level of Pregnant Women Under the Age of 20 Years in Dealing with pregnancy.

\begin{tabular}{ccccc}
\hline Readiness & $\mathbf{N}$ & SD & SE & p-value \\
\hline Before & 30 & 1,95 & 0,357 & 0.000 \\
\hline After & 30 & 1,96 & 1,11 & \\
\hline
\end{tabular}

Table 5 shows that the average readiness of pregnant women under the age of 20 years before being given antenatal education with the booklet media is 27.63 with a standard deviation of 1.95. Pregnant women who are exposed to antenatal education with the booklet media average readiness is 31.93 and standard deviations 1.96 . The statistical test obtained $\mathrm{p}$ value $=0.000$. Thus, it can be concluded that there is a 
significant effect on the readiness of pregnant women under the age of 20 in dealing with pregnancy.

a. Characteristics of Respondents

Based on the results of the study, 20 pregnant women $(66.6 \%)$ aged $18-20$ years which the age of most respondents ranged between 16-19 years. Based on the theory of the development of the age, 15-17 years old is in the category of middle adolescents and ages 18-20 years are the late teens. In this period, a transition process occurs between children and adults, a time when there are enormous biological, intellectual, psychosocial, and economic changes (Huang et al., 2007; Wong, 2012).

Maturity of a person's mindset will influence in behaving and acting according to the theory which stated that the higher the level of knowledge and experience possessed, the more mature the pattern or way of thinking in dealing with something. Therefore, more age and experience of a person will affect the readiness and activeness in dealing with everything (Qurniasih, N., \& Nawangsih, U.H.E. 2014). It is reinforced by the results of Susanti et al., (2014) research on "Knowledge of Pregnant Women Attending Pregnant Women Classes about Management of Non-Pharmacological Labor Pain in the Working Area of the Beard Primary Health Center" which stated that, knowledge is influenced by several factors including age, education, work, experience, environment, and culture.

The level of education also determines whether or not someone easily absorbs and understands the knowledge they have acquired, the higher a person's education, the more quality knowledge and the more mature his intelligence. In this study, it was seen that the respondents with the most education were 19 junior high schools $(63.4 \%)$. From research conducted by Restuastuti \& Ernalia (2012), the higher the level of education, the higher the level of knowledge about the risk of pregnancy. The level of education can affect one's mindset and digestibility of information. The higher the level of one's education, the higher the information that can be absorbed and affect the level of knowledge (Edrin et al., 2014). Damayanti and Nur, (2010) revealed that if a pregnant woman has more knowledge about the high risk of pregnancy, the possibility of the mother will behave to prevent, avoid and overcome the problem of the risk of pregnancy.

Based on the results of this study, the work of 30 respondents found $100 \%$ of pregnant women work as housewives. Thus, mothers generally have a lot of time at home compared to mothers who work so they have a lot of time to look for information about nursing care. The existence and ease of accessing information at present including television, radio and print media, however, internet through mobile phone is one of the factors that can increase knowledge by obtaining more and varied information (Montung et al., 2016).

b. Characteristics of knowledge level and readiness in dealing with pregnancy

Based on the results of this study, it is indicated that the average level of knowledge before being given antenatal education with booklet medias has increased the average value after being given antenatal education with booklet medias. The minimum and maximum values of the pretest and posttest were also increased. The minimum and maximum pretest values of 3-7 and after the posttest became 8-10. From these results, it can be seen that there are changes in values before and after being given education with the booklet media, on the knowledge pretest questionnaire results with 
30 respondents pregnant women under the age of 20 years before being given antenatal education.

The booklet media helps increasing the knowledge of pregnant women through communicative messages that are accompanied by attractive visuals so that pregnant women can easily understand the content of the messages contained in the booklet because in theory of health education, it is provided by other people with the help of media that are read or heard repeatedly as in the form of leaflets, slides, booklets and the others accompanied by attractive visuals in the form of photos and images which can remember $20-50 \%$ of the information received. It is in accordance with a study conducted by Damanik et al., (2015). The level of knowledge of Primigravida mothers about the danger signs of pregnancy before and after counseling in the working area of the Rejosari Community Health Center. There were an increase in the number of respondents with good knowledge which was $16 \%$ of respondents and a decrease in the number of respondents with less knowledge.

Based on the results of this study, it is indicated that the average level of readiness before being given antenatal education with the booklet media is 27.63 and after being given antenatal education with the booklet media, the average became 31.93. Hence, there was an increase in the average value of readiness after being given antenatal education with the booklet media. There had also been an increase in the minimum and maximum values of the pretest and posttest, with the minimum and maximum pretest values of 24-32 and the posttest being 28-36. From these results, it can be seen that there is a change in the level of readiness before and after being given antenatal education with the booklet media.

In the pretest questionnaire results of maternal readiness with 30 respondents, pregnant women under the age of 20 years before being given antenatal education from 10 pretest statements obtained results in statement number 8 about whether knowing the correct way of pregnancy care, it obtained the lowest score of 45 where the results of this statement can be caused because respondents have not been exposed to information about proper pregnancy care. Furthermore, the questionnaire statements number 4 and 6 had the highest score of 106 where some respondents received support from the family for their pregnancy and consumed a nutritious meal. Meanwhile, the questionnaire results of pregnant women readiness under 20 years after being given antenatal education shows that from the 10 items of the posttest statement, it was obtained the results of statements regarding pregnancy concerns due to age under 20 years, and it was obtained the lowest score of 70 where the results of this statement can be caused by respondents knowing the risk of pregnancy under 20 years old so it can be more careful and alert to pregnancy. Moreover, the questionnaire statement number 6 head the highest score of 110 where most agreed to consume nutritious food that is complete.

The results of a study conducted by Rokhanawati, D., \& Edi Nawangsih, U (2017) showed that prior to the intervention, 19 respondents $(44.2 \%)$ were ready to face the first pregnancy, while 24 respondents $(55.8 \%)$ were not yet ready for the first pregnancy. After the intervention, based on the results of the post-test questionnaire, it was noted that 26 respondents $(60.5 \%)$ were ready to face the first pregnancy and 17 respondents $(39.5 \%)$ were still not ready to face the first pregnancy. Assessment of respondents' readiness used a questionnaire that covers physical, psychological, social and cognitive aspects. Changes in readiness in facing the first pregnancy occur because of additional information received by respondents. The information was held through premarital education conducted by the researchers. 
c. Analysis of the effect of antenatal education on knowledge in dealing with childbirth of under 20 years mother in dealing with pregnancy

Based on the Wilcoxon Test Results, it obtained on the knowledge variable with a significance value of 0.000 . From the results of the significance value $(p)$ obtained $p=$ $0.000<\alpha=0.05$. Thus, it can be concluded that there is an influence of antenatal education with the booklet media on the knowledge of pregnant women under the age of 20 in dealing with pregnancy.

In this study, in addition to using the lecture method, researchers also used a booklet media to attract mothers' interests and increase their understanding of the material presented. Giving material that is only by the lecture method without any other media that can be re-read by the mother such as a booklet can cause the mother to forget the material that has been delivered previously. The difference in knowledge of pregnant women before and after being given antenatal education with booklet medias can be caused by several factors including the characteristics of pregnant women, the delivery of material that is focused, the media used such as booklets that mothers can read back at home and evaluations conducted after being given antenatal education with the booklet media and mothers are allowed to ask if they do not understand the material presented, so that mothers can understand the materials.

It is in accordance with the research results of Fatimah et al., 2017 which also showed that health education with booklet media can be very effective in increasing knowledge in mothers according to Rathore et al., (2014) and Fernandes et al., (2013) so that it proves that health education has an antenatal influence on the knowledge pregnant mother.

d. Analyze the effect of antenatal education on the preparedness of pregnant women under 20 years of age in dealing with pregnancy.

From the Paired Sample T Test Results, it obtained the readiness variable with a significance value of 0.000 . From the results of the significance value $(p)$ obtained $p=$ $0.000<\alpha=0.05$. Thus, it can be concluded that there is an effect of antenatal education with the booklet media on the readiness of pregnant women under the age of 20 in dealing with pregnancy.

In this study, in addition to use the lecture method, researchers also used a booklet media to attract mothers' interests and increase their understanding of the material presented. Giving material that is only by the lecture method without any other media that can be re-read by the mother such as a booklet can make mother forget the material that has been delivered previously. The difference in the readiness of pregnant women before and after being given antenatal education with the booklet media can be caused by several factors including the characteristics of pregnant women, the delivery of material that is focused, the media used such as booklets that mothers can read back at home and evaluations conducted after being given antenatal education with the booklet media and mothers are allowed to ask if they do not understand the material presented, so that mothers can understand better the materials. Better understanding the material can increase the readiness of pregnant women under the age of 20 in dealing with pregnancy, especially regarding antenatal education such as good pregnancy care and better prepared for things that will happen. This research was supported by Erawati et 
Ekayani, N. P. K., Nurmayasari \& Gumilang, I. (2020). Antenatal Education with Booklet Media on Knowledge and Readiness of Pregnant Women under the Age of 20 Years. JURNAL INFO KESEHATAN, 18(1), 50-58. https://doi.org/10.31965/infokes.Vol18.Iss1.311

al., (2016) which said that the knowledge and attitudes of pregnant women could be improved through health education.

\section{CONCLUSION}

Antenatal education with the booklet media significantly influences the knowledge and readiness of pregnant women under the age of 20 in dealing with pregnancy in the working area of the Technical Service Unit of Primary Health Center, Gerung in 2019.

\section{REFERENCES}

Badan Pusat Statistik. (2017). Survei Demografi dan Kesehatan Indonesia tahun 2017. Jakarta : Badan Pusat Statistik.

Badan Pusat Statistik. (2017). Statistik Daerah Kota Mataram. Badan Pusat statistik Kota Mataram.

Badan Pusat Statistik. (2018). Statistik Daerah Lombok Barat. Badan Pusat Statistik Lombok Barat.

Damanik, F., Fadilayana, Restuastuti T.,Noviardi. (2015). Tingkat Pengetahuan Ibu Primigravida Tentang Tanda Bahaya Kehamilan Sebelum dan Sesudah Penyuluhan Di Wilayah Kerja Puskesmas Rejosari. Jom FK, 2(2), 1-13.

Damayanti, E., \& Nur, A. (2010). Hubungan tingkat pengetahuan ibu hamil tentang resiko tinggi kehamilan dengan kepatuhan kunjungan antenatal care di RSUD Pandan Arang Boyolali. Jurnal Keperawatan, 3(4), 174-182.

Edrin, V. L., Ariadi, A., \& Irawati, L. (2014). Gambaran karakteristik ibu hamil pada persalinan preterm di RSUP Dr. M. Djamil Padang tahun 2012. Jurnal Kesehatan Andalas, 3(3), 311-317. DOI: https://doi.org/10.25077/jka.v3i3.110

Erawati, L., Fuadah, D. Z., \& Sunaringtyas, W. (2016). Pengaruh Pendidikan Kesehatan tanda Bahaya Kehamilan terhadap Sikap Ibu Hamil tentang Tanda Bahaya Kehamilan di BPM Ny. Fy Ds. Penataran Nglegok-Blitar. Jurnal Ners dan Kebidanan (Journal of Ners and Midwifery), 3(2), 95-100. DOI: 10.26699/jnk.v3i2.ART.p095-100

Fatimah, N., Royhanaty, I., \& Sawitry, S. (2017). Pengaruh Pendidikan Kesehatan Metode Peer Group Tentang Menstruasi Terhadap Kesiapan Menghadapi Menarche Pada Siswi SD Kelas V Di SD Pundenarum I Kecamatan Karangawen Kabupaten Demak. Interest: Jurnal Ilmu Kesehatan, 6(1), 46-50.

Fernandes, P., Paul, S., \& Savitha, B. (2013). Effectiveness of an information booklet on knowledge among staff nurses regarding prevention and management of perineal tear during normal delivery. Journal of Health and Allied Sciences $N U, 3(1), 3-7$.

Huang, Z.J., Wong, F.Y., Ronzio, C.R. and Yu, S.M. 2007. Depressive Symptomatology and Mental Health Help-Seeking Patterns of U.S.- and ForeignBorn Mothers. Matern Child Health J, 11: 257-267. DOI: https://doi.org/10.1007/s10995-006-0168-X

Kementerian Kesehatan, R. I. (2018). Laporan Nasional Riskesdas 2018. Jakarta: Badan Penelitian dan Pengembangan Kesehatan.

Montung, V. L., Adam, S. K., \& Manueke, I. (2016). Hubungan pengetahuan dengan perilaku ibu hamil trimester III dalam persiapan persalinan. JIDAN (Jurnal Ilmiah Bidan), 4(1), 44-49. 
Nedra, W., Soedjatmiko, S., \& Firmansyah, A. (2006). Kesiapan Fisik Dan Pengetahuan Remaja Perempuan Sebagai Calon Ibu Dalam Membina Tumbuh Kembang Balita Dan Faktor-Faktor Yang Mempengaruhinya. Sari Pediatri, 8(3), 209-217.

Oktalia J., Herizasyam. (2016). Kesiapan Ibu Menghadapi Kehamilan Dan FaktorFaktor Yang Mempengaruhinya. Jurnal Ilmu dan Teknologi Kesehatan, 3(2), 147159.

Qurniasih, N., \& Nawangsih, U. H. E. (2014). Hubungan Aktivitas Kelas Ibu Hamil Terhadap Kesiapan Ibu Hamil Dalam Menghadapi Persalinan di Puskesmas Gedongtengen Yogyakarta 2014. Skripsi. Yogyakarta: STIKES 'Aisyiyah Yogyakarta.

Rathore, C. K., Pandya, A., \& Ravindra, H. N. (2014). Effectiveness of Information Booklet on Knowledge Regarding Home Menegement of Selected Common Illness in Children. IOSR Journal of Nursing and Health Science (IOSRJNHS),3(5), 80-84.

Restuastuti, T., Handayani, E. Y., \& Ernalia, Y. (2012). Pengetahuan dan sikap ibu hamil tentang kehamilan risiko tinggi sebelum dan sesudah penyuluhan di wilayah kerja Puskesmas Muara Fajar Kota Pekanbaru. Riau: Fakultas Kedokteran Universitas Riau.

Rokhanawati, D., \& Edi Nawangsih, U. (2017). Pendidikan pranikah terhadap kesiapan menghadapi kehamilan pertama pada calon pengantin putri. Jurnal Kebidanan dan Keperawatan Aisyiyah, 13(1), 81-87. DOI:https://doi.org/10.31101/jkk.317

Susanti, W. S., Aisyah, R. D., \& Khanifah, M. (2014). Pengetahuan Ibu Hamil yang Mengikuti Kelas Ibu Hamil Tentang Manajemen Nyeri Persalinan Non Farmakologi. Jurnal Ilmiah Kesehatan, 6(1).

Wong, L. P. (2012). An exploration of knowledge, attitudes and behaviours of young multiethnic Muslim-majority society in Malaysia in relation to reproductive and premarital sexual practices. BMC public health,12(1),1-13.DOI: https://doi.org/10.1186/1471-2458-12-865

Zulaekah, S. (2012). Pendidikan Gizi Dengan Media Booklet Terhadap Pengetahuan Gizi. KEMAS: Jurnal Kesehatan Masyarakat, 7(2), 127-133. 